\title{
Structure and Reactivity of the Magnesium Alkyl-2-Alkoxyethanol System as an Initiator for Styrene Polymerization
}

\author{
Tadashi Narita, Takashi Yasumura, and Teiji Tsuruta \\ Department of Synthetic Chemistry, Faculty of Engineering, \\ The University of Tokyo, Bunkyo-ku, Tokyo, Japan.
}

(Received August 5, 1972)

\begin{abstract}
The structure and reactivity of dialkylmagnesium-2-alkoxyethanol system as an initiator for styrene polymerization were studied. Dialkylmagnesium coupled with an equimolar quantity of 2-alkoxyethanol was found to initiate styrene polymerization, although the use of dialkylmagnesium alone could not induce polymerization. Metalation reaction of fluorene and addition reaction to 1,1-diphenylethylene were possible with dialkylmagnesium-2-alkoxyethanol system. Measurements of the electronic spectra of these carbanion solutions indicated that coordination-agentseparated ion pairs were produced in the system. The colorless prism crystal, which was formed in di-n-butylmagnesium-2-methoxyethanol system, was found to possess a composition such as $n-\mathrm{C}_{4} \mathrm{H}_{9} \mathrm{MgOCH}_{2} \mathrm{CH}_{2} \mathrm{OCH}_{3} \cdot \mathrm{Mg}\left(\mathrm{OCH}_{2} \mathrm{CH}_{2} \mathrm{OCH}_{3}\right)_{2}$. This complex exhibited high reactivity for styrene polymerization.

KEY WORDS Polymerization / Styrene / Dialkylmagnesium / 2Methoxyethanol / Tetrahydrofurfuryl Alcohol / Fluorene / 1,1Diphenylethylene / Coordination-Agent-Separated Ion Pair /
\end{abstract}

It was reported in a previous paper ${ }^{1}$ that in a hydrocarbon solvent the reactivity of styrene in the early stages of styrene-butadiene copolymerization was increased by the $n$-butyllithium$\mathrm{CH}_{3} \mathrm{OCH}_{2} \mathrm{CH}_{2} \mathrm{OLi}$ initiator system and copolymers containing more styrene units than the feed monomer ratio were formed. Electronic spectral measurements of the reaction product of the initiator system with 1,1-diphenylethylene indicated that two moles of $\mathrm{CH}_{3} \mathrm{OCH}_{2} \mathrm{CH}_{2} \mathrm{OLi}$ had interactions with one mole of the organolithium compound. A possible structure for the catalyst species was proposed. ${ }^{2}$ Electronic spectra of 9-fluorenyllithium indicated that an ion pair of a solvent-separated type predominated if double the molar quantity of $\mathrm{CH}_{3} \mathrm{OCH}_{2} \mathrm{CH}_{2} \mathrm{OLi}$ was added. This type of ion pair which was produced with the aid of a small amount of additive was proposed to be referred to as a "coordination-agent-separated" ion pair. ${ }^{2}$ The agent-separated ion pair was also observed in the system of organolithium compounds with some "crown" compounds.

The purpose of this work was to examine the effect of 2-methoxyethanol on the reactivity of dialkylmagnesium in the polymerization and metalation reactions.

\section{EXPERIMENTAL}

Most of the experiments were carried out in a purified nitrogen atmosphere in order to exclude oxygen and moisture.

\section{Reagents}

Diethyl ether, dioxane, toluene and cyclohexane were purified by the usual methods, refluxed over sodium wire and distilled. Styrene and butadiene were purified by the usual method. 1,1-Diphenylethylene was synthesized according to the literature. ${ }^{5}$ Commercial fluorene was recrystallized from ethanol. 2-Methoxyethanol was refluxed over calcium hydride and distilled under atmospheric pressure. Other commercial reagents were purified carefully. Di- $n$-butylmagnesium and diethylmagnesium were prepared according to the literature ${ }^{6}$ and used as dioxane solution. The concentration of dialkylmagnesium was determined by acid-base titration.

\section{Procedures}

The method of polymerization of styrene, 


\section{T. Narita, T. Yasumura, and T. Tsuruta}

copolymerization of styrene with butadiene, and analysis of copolymer were as reported elsewhere. ${ }^{1}$ The viscosity of polystyrene was measured at $30^{\circ} \mathrm{C}$ in benzene. The molecular weight of polystyrene was calculated from its limiting viscosity number according to the equation

$$
[\eta]=0.75 \times 10^{-4} M_{v}^{0.783}
$$

The extent of reaction between di- $n$-butylmagnesium and 2-methoxyethanol was determined by VPC. A colorless crystalline substance was deposited out of a reaction mixture of di- $n$ butylmagnesium ( $12 \mathrm{mmol}$ ) with 2-methoxyethanol $(18 \mathrm{mmol})$ in dioxane $(10 \mathrm{ml})$ at room temperature. The crystalline compound separated was dissolved again in THF and the mole per cent of magnesium analyzed by acid-base titration. Analysis of the other groups $\left(n-\mathrm{C}_{4} \mathrm{H}_{9^{-}}\right.$, $\mathrm{CH}_{3} \mathrm{OCH}_{2} \mathrm{CH}_{2} \mathrm{O}_{-}$, and dioxane) present in the crystalline compound was carried out by VPC after decomposing it with methanol.

9-fluorenylmagnesium derivative was prepared by adding fluorene $(1 \mathrm{mmol})$ to the dioxane $(50 \mathrm{ml})$ solution of di-n-butylmagnesium (2.5 $\mathrm{mmol}$-2-methoxyethanol $(4 \mathrm{mmol})$ system at room temperature.

1, 1-Diphenyl- $n$-butylmagnesium derivatives were prepared by adding 1,1-diphenylethylene $(15 \mathrm{mmol})$ to the THF $(50 \mathrm{ml})$ solution of $\mathrm{C}_{2} \mathrm{H}_{5} \mathrm{MgOCH}_{2} \mathrm{CH}_{2} \mathrm{OCH}_{3} \cdot \mathrm{Mg}\left(\mathrm{OCH}_{2} \mathrm{CH}_{2} \mathrm{OCH}_{3}\right)_{2}$ or $\left.\mathrm{C}_{2} \mathrm{H}_{5} \mathrm{MgOCH}_{2}-\mathrm{O}_{\backslash} \cdot \mathrm{Mg}\left(\mathrm{OCH}_{2}-\mathrm{O}_{\backslash}\right)_{2}\right)_{2}(9 \mathrm{mmol})$ at $50^{\circ} \mathrm{C}$.

Electronic spectra were recorded by means of a Shimadzu multipurpose recording photoelectric spectrometer, Type MPS-50 L, using $0.1-\mathrm{cm}$ quartz cell.

\section{RESULTS AND DISCUSSION}

\section{Polymerization Reaction of Styrene and Butadiene by Organomagnesium Initiator System}

Results of styrene polymerization initiated by di- $n$-butylmagnesium coupled with some additives are summarized in Table I.

Although dialkylmagnesium in toluene did not initiate styrene polymerization, dialkylmagnesium-2-methoxyethanol (Cell) system exhibited great activity for styrene polymerization. $N, N$, $N^{\prime}, N^{\prime}$-Tetramethylethylenediamine (TMEDA) or
Table I. Polymerization of styrene by the alkylmagnesium catalyst system ${ }^{a}$

\begin{tabular}{|c|c|c|c|}
\hline \multicolumn{2}{|l|}{ Catalyst, $\mathrm{mmol} / \mathrm{mmol}$} & $\underset{\mathrm{hr}}{\text { Time, }}$ & $\begin{array}{c}\text { Yield, } \\
\%\end{array}$ \\
\hline \multirow[t]{2}{*}{$\left(n-\mathrm{C}_{4} \mathrm{H}_{9}\right)_{2} \mathrm{Mg}$} & $2 / 0$ & 6 & 0 \\
\hline & & 24 & trace $^{b}$ \\
\hline \multirow{4}{*}{$\left(n-\mathrm{C}_{4} \mathrm{H}_{9}\right)_{2} \mathrm{Mg}-\mathrm{Cell}$} & $2 / 2$ & 6 & 28 \\
\hline & & 24 & 92 \\
\hline & & 6 & $77^{b}$ \\
\hline & & 6 & trace ${ }^{c}$ \\
\hline$-n-\mathrm{C}_{4} \mathrm{H}_{9} \mathrm{OH}$ & $2 / 2$ & 6 & 0 \\
\hline -TMEDA & $2 / 4$ & 24 & trace \\
\hline -Glyme & $2 / 4$ & 24 & 0 \\
\hline -НMPT & $2 / 4$ & 6 & 100 \\
\hline
\end{tabular}

a Monomer, $50 \mathrm{mmol}$; toluene, $25 \mathrm{ml} ; 40^{\circ} \mathrm{C}$.

b Monomer, $50 \mathrm{mmol}$; in THF; $40^{\circ} \mathrm{C}$.

c Monomer, $50 \mathrm{mmol}$; in cyclohexane; $40^{\circ} \mathrm{C}$.

Table II. Polymerization of styrene by the alkylmagnesium-Cell and related compounds system ${ }^{\mathrm{a}}$

\begin{tabular}{cccc}
\hline \multicolumn{2}{c}{ Catalyst, $\mathrm{mmol} / \mathrm{mmol}$} & Time, hr & Yield, $\%$ \\
\hline$\left(n-\mathrm{C}_{4} \mathrm{H}_{9}\right)_{2} \mathrm{Mg}$-Cell & $2 / 2$ & 6 & 28 \\
- DMAE & $2 / 2$ & 6 & 1 \\
-Car & $2 / 2$ & 24 & 1 \\
- Gua & $2 / 2$ & 24 & 3 \\
- THFA & $2 / 2$ & 0.5 & 100
\end{tabular}

a Monomer, $50 \mathrm{mmol}$; toluene, $25 \mathrm{ml} ; 40^{\circ} \mathrm{C}$.

ethylene glycol dimethylether (glyme), which are widely known to be an excellent complexing agent for organolithium compounds, showed no effect.

The effect of compounds possessing a similar structure to 2-methoxyethanol on the reactivity of di-n-butylmagnesium was examined, and results obtained are summarized in Table II. It was to be noted that tetrahydrofurfuryl alcohol (THFA) promoted markedly the reactivity of the organomagnesium compound, whereas 2dimethylaminoethanol (DMAE), methyl carbitol (Car), and guaiacol (Gua) showed little enhancing effect.

Results of homopolymerization of butadiene and of copolymerization of styrene with butadiene are shown in Table III. Even the di- $n$ butylmagnesium-Cell and -THFA initiator system showed only low reactivity for butadiene polymerization. 1,2-Structure predominated in 
Table III. Butadiene polymerization and butadiene-styrene copolymerization by the alkylmagnesium system $^{\mathrm{a}}$

\begin{tabular}{|c|c|c|c|c|c|c|c|c|}
\hline \multirow{2}{*}{ Monomer } & \multirow{2}{*}{\multicolumn{2}{|c|}{ Catalyst, $\mathrm{mmol} / \mathrm{mmol}$}} & \multirow{2}{*}{$\begin{array}{c}\text { Time, } \\
\text { day }\end{array}$} & \multirow{2}{*}{$\underset{\%}{\text { Yield, }}$} & \multirow{2}{*}{$\begin{array}{l}\text { Styrene in } \\
\text { copolymer, \% }\end{array}$} & \multicolumn{3}{|c|}{$\begin{array}{c}\text { Microstructure of } \\
\text { butadiene, } \%\end{array}$} \\
\hline & & & & & & trans & vinyl & cis \\
\hline \multirow[t]{4}{*}{ Butadiene } & $\left(n-\mathrm{C}_{4} \mathrm{H}_{9}\right)_{2} \mathrm{Mg}-\mathrm{Cell}$ & $2 / 2$ & 1 & 0 & - & - & - & - \\
\hline & & $3 / 4$ & 3 & 4 & - & 10 & 90 & 0 \\
\hline & & & 3 & $\operatorname{trace}^{b}$ & 一 & - & - & 一 \\
\hline & -THFA & $2 / 2$ & 3 & 13 & - & 11 & 89 & 0 \\
\hline \multirow[t]{4}{*}{ Butadiene-Styrene } & $\left(n-\mathrm{C}_{4} \mathrm{H}_{9}\right)_{2} \mathrm{Mg}-$ Cell & $2 / 2$ & 9 & 2 & 81 & 39 & 61 & 0 \\
\hline & & & 3 & $21^{b}$ & 73 & 28 & 72 & 0 \\
\hline & & $3 / 4$ & 3 & 53 & 66 & 18 & 82 & 0 \\
\hline & -THFA & $2 / 2$ & 3 & 2 & - & - & - & 一 \\
\hline
\end{tabular}

a Butadiene, $50 \mathrm{mmol}$; butadiene-styrene in feed $25 \mathrm{mmol} / 25 \mathrm{mmol}$; toluene, $25 \mathrm{ml} ; 40^{\circ} \mathrm{C}$.

b Butadiene, $50 \mathrm{mmol}$; butadiene-styrene in feed $25 \mathrm{mmol} / 25 \mathrm{mmol}$; THF; $40^{\circ} \mathrm{C}$.

the butadiene-homopolymer and - copolymer produced by these initiator systems. The styrene content of the copolymer was found to be highsimilar to the copolymer with alkyllithium$\mathrm{CH}_{3} \mathrm{OCH}_{2} \mathrm{CH}_{2} \mathrm{OLi}$ initiator system. Hexamethylphosphoric triamide (HMPT), which was reported to enhance the reactivity of a Grignard reagent, ${ }^{7,8}$ had an enormous effect on the reactivity of dibutylmagnesium in this polymerization (Table I). Analyses of Organomagnesium Initiator System

The reaction of di- $n$-butylmagnesium with 2methoxyethanol was examined. After $n$-butane, which was produced from the reaction of di- $n$ butylmagnesium with 2-methoxyethanol, had been evaporated, the residual white solid was dissolved again in dioxane and decomposed by methanol. Analysis for $n$-butane produced in this reaction (Table IV) indicated that the reaction of di- $n$-butylmagnesium with 2-methoxyethanol proceeded stoichiometrically. In accordance with this, no infrared peaks assignable
Table IV. Reaction of $\left(n-\mathrm{C}_{4} \mathrm{H}_{9}\right)_{2} \mathrm{Mg}$ with $\mathrm{CH}_{3} \mathrm{OCH}_{2} \mathrm{CH}_{2} \mathrm{OH}^{\mathrm{a}}$

\begin{tabular}{|c|c|c|c|}
\hline \multicolumn{2}{|c|}{ Starting materials } & \multicolumn{2}{|c|}{$\begin{array}{c}\text { Recovered } \\
n-\mathrm{C}_{4} \mathrm{H}_{10}\end{array}$} \\
\hline $\begin{array}{c}\left(n-\mathrm{C}_{4} \mathrm{H}_{9}\right)_{2} \mathrm{Mg} \\
\mathrm{mmol}\end{array}$ & $\underset{\mathrm{mmol}}{\mathrm{CH}_{3} \mathrm{OCH}_{2} \mathrm{CH}_{2} \mathrm{OH}}$ & $\begin{array}{l}\text { Calcd, } \\
\text { mmol }\end{array}$ & $\begin{array}{l}\text { Found } \\
\text { mmol }\end{array}$ \\
\hline 2.0 & 2.0 & 2.0 & 2.1 \\
\hline 3.0 & 4.0 & 2.0 & 2.0 \\
\hline 4.0 & 6.0 & 2.0 & 1.7 \\
\hline 2.0 & 4.0 & 0 & 0 \\
\hline
\end{tabular}

a In dioxane, $1 \mathrm{hr}$.

b Analyzed by VPC after drying up and dissolved in dioxane.

to the $\mathrm{O}-\mathrm{H}$ group were observed in the reaction system. In an equimolar reaction, the reaction could primarily be described as follows.

$$
\begin{array}{r}
\left(n-\mathrm{C}_{4} \mathrm{H}_{9}\right)_{2} \mathrm{Mg}+\mathrm{CH}_{3} \mathrm{OCH}_{2} \mathrm{CH}_{2} \mathrm{OH} \longrightarrow \\
{ }_{n}-\mathrm{C}_{4} \mathrm{H}_{9} \mathrm{MgOCH}_{2} \mathrm{CH}_{2} \mathrm{OCH}_{3}+n-\mathrm{C}_{4} \mathrm{H}_{10}
\end{array}
$$

Table $\mathrm{V}$ shows the influence of the added

Table V. Effect of $[\mathrm{OMg}] /[\mathrm{CMg}]$ on the polymerization of styrene ${ }^{\mathrm{a}}$

\begin{tabular}{cccccc}
\hline $\begin{array}{c}\left(n-\mathrm{C}_{4} \mathrm{H}_{9}\right)_{2} \mathrm{Mg}, \\
\mathrm{mmol}\end{array}$ & $\begin{array}{c}\mathrm{CH}_{3} \mathrm{OCH}_{2} \mathrm{CH}_{2} \mathrm{OH}, \\
\mathrm{mmol}\end{array}$ & $\begin{array}{c}{[\mathrm{OMg}] /[\mathrm{CMg}],} \\
\mathrm{mmol} / \mathrm{mmol}\end{array}$ & Time, hr & Yield, \% & {$[\eta]^{\mathrm{b}}, \mathrm{d} l / \mathrm{g}$} \\
\hline 1.0 & 1.0 & $1 / 1$ & 1 & 8 & 2.9 \\
1.5 & 2.0 & $2 / 1$ & 1 & 36 & 3.0 \\
2.0 & 3.0 & $3 / 1$ & 1 & 100 & 3.4 \\
2.5 & 4.0 & $4 / 1$ & 1 & 100 & 2.8 \\
2.0 & 4.0 & $4 / 0$ & 24 & 0 & - \\
\hline
\end{tabular}

a Monomer, $50 \mathrm{mmol}$; toluene, $25 \mathrm{ml} ; 40^{\circ} \mathrm{C}$.

b In benzene at $30^{\circ} \mathrm{C}$. 
amount of 2-methoxyethanol on the extent of styrene polymerization while keeping the feed concentration of $\mathrm{C}-\mathrm{Mg}$ constant. The yield of polystyrene was increased enormously under the condition $[\mathrm{OMg}] /[\mathrm{C}-\mathrm{Mg}] \geqq 3$. The limiting viscosity number of the polystyrene formed was nearly constant at a value of 3 . The molecular weight of the polymer was estimated to be about $7 \times 10^{5} . \mathrm{Mg}\left(\mathrm{OCH}_{2} \mathrm{CH}_{2} \mathrm{OCH}_{3}\right)_{2}$ did not produce polystyrene.

White precipitates were produced in a few minutes when di-n-butylmagnesium was reacted with 2-methoxyethanol at a molar ratio of either one to one or two to three. The white precipitates could be recrystallized to form colorless prism crystals. The crystals were easily soluble in tetrahydrofuran and toluene, and showed high reactivity as initiators for styrene polymerization. Analyses of the crystals showed the following composition:

$\mathrm{Mg}: n-\mathrm{C}_{4} \mathrm{H}_{9}: \mathrm{CH}_{3} \mathrm{OCH}_{2} \mathrm{CH}_{2} \mathrm{O}=2.0: 1.06: 3.05$

The crystals also contained half a mole of dioxane to magnesium as solvent of crystallization.
The crystalline precipitates produced in the initiator system were, therefore, concluded to be composed primarily of

$$
\begin{aligned}
& n-\mathrm{C}_{4} \mathrm{H}_{9} \mathrm{MgOCH}_{2} \mathrm{CH}_{2} \mathrm{OCH}_{3} \cdot \\
& \qquad \mathrm{Mg}\left(\mathrm{OCH}_{2} \mathrm{CH}_{2} \mathrm{OCH}_{3}\right)_{2} \text {. Dioxane. }
\end{aligned}
$$

The electronic spectrum of the compound produced from the reaction of $\left(n-\mathrm{C}_{4} \mathrm{H}_{9}\right)_{2} \mathrm{Mg}$ $\mathrm{CH}_{3} \mathrm{OCH}_{2} \mathrm{CH}_{2} \mathrm{OH}$ system with fluorene was examined in order to get information about the ionic character of the initiator system. The result is shown in Figure 1. A single peak at $373 \mathrm{~nm}$ was observed for the 9-fluorenylmagnesium derivative. This absorption is in accordance with the solvent-separated ion pair. ${ }^{9-12}$ This kind of species is considered most likely to correspond to a coordination-agent-separated ion pair, as reported for the organolithium system. $^{2}$ However, this consideration is not conclusive enough, because the spectrum of the true contact ion-pair cannot be measured by electronic spectra owing to the lack of a preparative method of difluorenylmagnesium in the absence of a strong base such as HMPT.

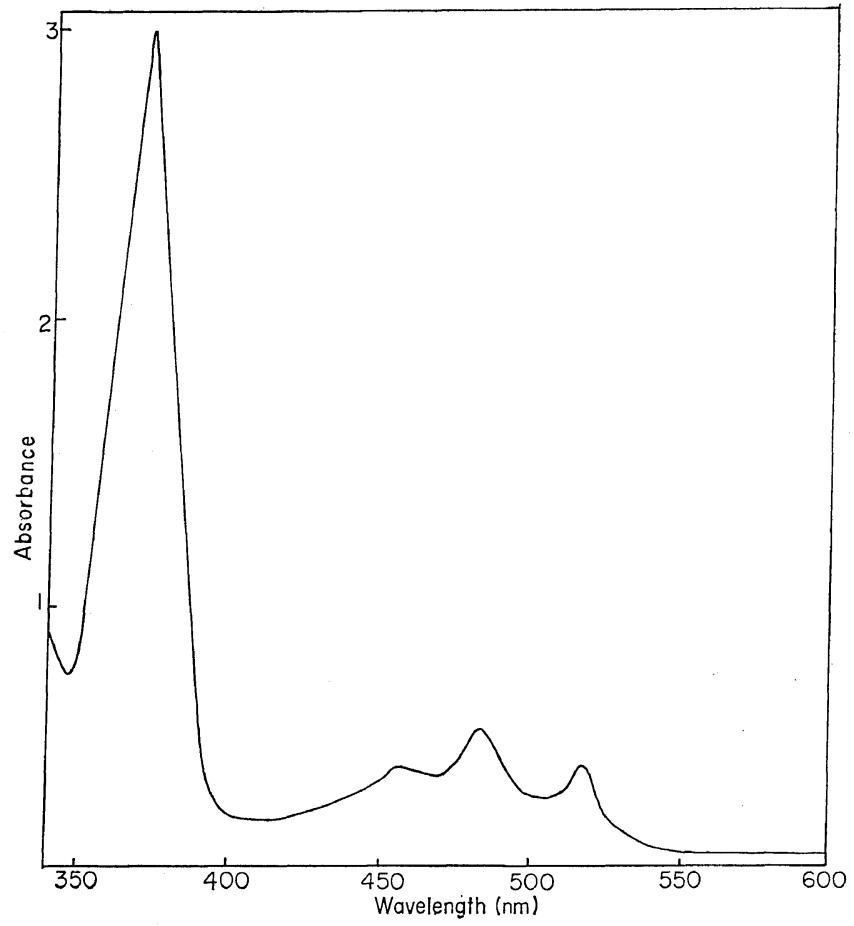

Figure 1. UV spectrum of the fluorenylmagnesium derivative: $\left(n-\mathrm{C}_{4} \mathrm{H}_{9}\right)_{2} \mathrm{Mg}, 2.5$ mmol; $\mathrm{CH}_{3} \mathrm{OCH}_{2} \mathrm{CH}_{2} \mathrm{OH}, 4 \mathrm{mmol}$; fluorene, $1 \mathrm{mmol}$. 


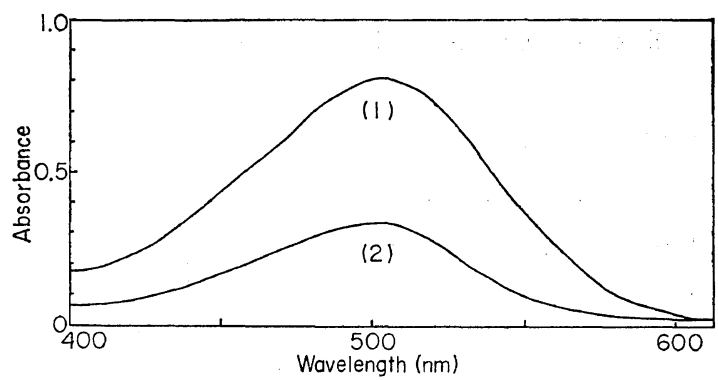

Figure 2. UV spectra of the reaction product of $\mathrm{CH}_{2}=\mathrm{C}\left(\mathrm{C}_{6} \mathrm{H}_{5}\right)_{2}$ with

(1) $\mathrm{EtMgOCH}_{2} \mathrm{CH}_{2} \mathrm{OCH}_{3} \cdot\left(\mathrm{CH}_{3} \mathrm{OCH}_{2} \mathrm{CH}_{2} \mathrm{O}\right)_{2} \mathrm{Mg}$;

(2) $\mathrm{EtMgOCH}_{2}-\mathrm{O} /\left(\mathrm{O}_{-}-\mathrm{CH}_{2} \mathrm{O}\right)_{2} \mathrm{Mg}$.

Figure 2 shows the electronic spectra of the 1,1-diphenyl- $n$-butylmagnesium derivatives. The spectra showed $\lambda_{\max }$ at $501 \mathrm{~nm}$ and $503 \mathrm{~nm}$ for $\mathrm{CH}_{3} \mathrm{OCH}_{2} \mathrm{CH}_{2} \mathrm{OH}$ system and THFA system, respectively. Since these values show large bathochromic shifts compared with those of 1,1diphenyl- $n$-hexyllithium- $\mathrm{CH}_{3} \mathrm{OCH}_{2} \mathrm{CH}_{2} \mathrm{OLi}$ system reported recently, ${ }^{2}$ the magnesium alkoxide, $\left(\mathrm{CH}_{3} \mathrm{OCH}_{2} \mathrm{CH}_{2} \mathrm{O}\right)_{2} \mathrm{Mg}$, is considered to have a strong interaction with the organomagnesium compounds.

Since this initiator system produced high molecular weight polystyrene even when the polymerization was carried out with a rather low ratio of [monomer] to [initiator], the effective concentration of active species must be very low. This estimation was supported by anion concentrations derived from the results shown in Figures 1 and 2. By applying the molar extinction coefficients, $1.7 \times 10^{4}$ and $2.5 \times 10^{4}$ for fluorenylsodium $^{10}$ and 1,1 -diphenyl-n-hexyllithium, ${ }^{13}$ respectively, the anion concentrations were estimated to be about $1 \%$ for fluorenylmagnesium derivatives and $0.05 \%$ for diphenylmethyl- magnesium derivatives under the experimental conditions. Polystyryl anion was, therefore, not measured quantitatively by electronic spectra owing to its low concentration.

Since no addition reaction products were detected by VPC from the reaction mixtures of $\mathrm{RMgOCH}_{2} \mathrm{CH}_{2} \mathrm{OCH}_{3} \cdot \mathrm{Mg}\left(\mathrm{OCH}_{2} \mathrm{CH}_{2} \mathrm{OCH}_{3}\right)_{2}$ with 1, 1-diphenylethylene after decomposed by methanol, the propagation reaction of styrene polymerization is presumably much more rapid than the initiation reaction, though the detailed mechanism of the initiation has not been elucidated.

\section{REFERENCES}

1. T. Narita, A. Masaki, and T. Tsuruta, $J$. Macromol. Sci.-Chem., A4, 277 (1970).

2. T. Narita and T. Tsuruta, J. Organometal. Chem., 30, 289 (1971).

3. K. H. Wong, G. Konizer, and J. Smid, $J$. Amer. Chem. Soc., 92, 666 (1970).

4. U. Takaki, T. H. Hogen-Esch, and J. Smid, ibid., 93, 6760 (1971).

5. C. F. H. Allen and S. Converse, "Organic Syntheses," Vol. 1, John Wiley \& Sons, Inc., New York, N. Y., 1941, p 226.

6. D. L. Cottle and W. C. Hollyday, Jr., J. Org. Chem., 12, 510 (1947).

7. U.S. Patent 3347912 (1967).

8. M. Tomoi and H. Kakiuchi, Kogyo Kagaku Zasshi (J. Chem. Soc. Japan, Ind. Chem. Sect.), 73, 2367 (1970).

9. T. H. Hogen-Esch and J. Smid, J. Amer. Chem. Soc., 87, 669 (1965).

10. T. H. Hogen-Esch and J. Smid, ibid., 88, 307 (1966).

11. L. L. Chan and J. Smid, ibid., 89, 4547 (1967).

12. L. L. Chan and J. Smid, ibid., 90, 4654 (1968).

13. R. Waack and M. A. Doran, J. Organometal. Chem., 29, 329 (1971). 